\title{
MEDIA DAUN-DAUN UNTUK MENINGKATKAN HASIL BELAJAR ALJABAR PESERTA DIDIK LAMBAN BELAJAR (SLOW LEARNER)
}

\section{Leaves as Media to Improve Algebra Learning Achievement of Slow Learner Students}

\author{
Dyah Sinto Rini \\ SMPN 18 Tangerang, Perum Poris Indah Blok G, Cipondoh, Kota Tangerang, 0215547469, Kode Pos 15148, \\ Indonesia \\ *)E-mail korespondensi: dyahsintorini@gmail.com
}

\begin{abstract}
The slow learner student often has difficulty to participate in the mathematics learning process. This classroom action research was conducted to improve algebra learning achievement of slow learner students in SMPN 18 Tangerang by using leaves as learning media. This research was planned for two cycles with the research subjects were 16 slow learner students of class VII.2 in SMPN 18 Tangerang in 2017-2018 academic year. The main data sources are learning achievement test, reflection sheet and learning documents. Data analysis at the end of the first cycle showed that there were 12 of 16 slow learner students achieved $\geq 70$ (the minimum completeness criteria), it meant that the percentage of learning completeness achieved 75\%. It was concluded that leaves as learning media could improve the algebra learning achievement of the slow learner students at SMPN 18 Tangerang. By utilizing leaves and with the guidance of teacher and other friends in the classroom, the slow learner students became interested and motivated to gain better understanding of algebraic material.
\end{abstract}

Keywords: achievement, algebra, leaves, slow learner.

\begin{abstract}
ABSTRAK
Penelitian tindakan kelas ini dilatarbelakangi oleh kenyataan bahwa sering dijumpai adanya peserta didik yang merasa kesulitan dan sangat lamban dalam mengikuti proses pembelajaran matematika. Peserta didik lamban belajar (slow learner) kurang mampu menguasai konsep matematika dalam batas waktu yang ditentukan sehingga mengakibatkan hasil belajar matematikanya rendah. Penelitian ini direncanakan sebanyak dua siklus dengan subyek penelitian 16 orang peserta didik lamban belajar di kelas VII.2 SMPN 18 Tangerang tahun pelajaran 2017/2018. Sumber data utamanya adalah tes hasil belajar, lembar refleksi dan dokumen pembelajaran. Analisis data pada akhir siklus I menunjukkan bahwa dari 16 orang peserta didik lamban belajar, terdapat 12 orang peserta didik lamban belajar yang memperoleh hasil belajar $\geq$ nilai kriteria ketuntasan minimal yaitu 70. Diperoleh persentase ketuntasan belajar sebesar 75\% dan indikator keberhasilan tercapai. Disimpulkan bahwa media daun-daun dapat meningkatkan hasil belajar aljabar peserta didik lamban belajar (slow learner) di SMPN 18 Tangerang. Dengan memanfaatkan media daun-daun serta bimbingan guru dan teman-teman peserta didik yang tidak lamban belajar, peserta didik lamban belajar menjadi tertarik dan termotivasi untuk lebih memahami materi aljabar.
\end{abstract}

Kata kunci: aljabar, daun-daun, hasil belajar, lamban belajar.

\section{PENDAHULUAN}

SMPN 18 Tangerang, sekolah tempat penulis mengajar terletak di pinggir timur Kota Tangerang, memiliki tiga puluh rombongan belajar dengan masing-masing tingkat terdiri dari sepuluh kelas. Karena itu, SMPN 18 Tangerang setiap tahunnya selalu mempunyai lebih dari seribu orang peserta didik dengan berbagai latar belakang sosial, budaya, ekonomi, agama maupun kemampuan intelektual yang beragam. Keberagaman latar belakang ini berkorelasi dengan tingkat pemahaman dalam belajar peserta didik yang berbeda pula.

Berdasarkan pengalaman penulis dalam mengajar mata pelajaran matematika, penulis sering menjumpai peserta didik yang merasa kesulitan dan sangat lambat dalam mengikuti proses pembelajaran serta kurang mampu menguasai konsep matematika dalam batas waktu yang ditentukan. Peserta didik yang memiliki kemampuan kurang dalam memahami pelajaran sehingga membutuhkan waktu yang lebih lama untuk memahami konsep materi yang disampaikan guru bisa dikategorikan sebagai peserta didik lamban belajar (slow learner). Ketidakmampuan dalam menguasai materi yang diajarkan, pada akhirnya mengakibatkan peserta didik lamban belajar hanya 
memperoleh hasil belajar matematika yang rendah. Bersumber dari laporan nilai mata pelajaran matematika kelas VII SMPN 18 Tangerang tahun pelajaran 2016/2017, peserta didik lamban belajar hampir selalu memperoleh skor hasil belajar kurang dari nilai kriteria ketuntasan minimal, baik untuk penilaian tugas, penilaian harian, penilaian tengah semester maupun penilaian akhir semester.

Pemerintah menyatakan bahwa lamban belajar termasuk salah satu jenis anak berkebutuhan khusus (ABK). ABK sangatlah beragam dan memiliki kekhususannya masing-masing. Peraturan Pemerintah nomor 17 tahun 2010 pasal 129 ayat 3 menjelaskan bahwa peserta didik berkelainan (berkebutuhan khusus) terdiri atas peserta didik yang: tunanetra; tunarungu; tunawicara; tunagrahita; tunadaksa; tunalaras; berkesulitan belajar; lamban belajar; autis; memiliki gangguan motorik. Laili (2013) menjelaskan bahwa anak lamban belajar (slow learner) adalah anak yang memiliki potensi intelektual sedikit di bawah anak normal, namun mereka tidak termasuk anak tuna grahita. Dalam beberapa hal anak ini mengalami beberapa hambatan atau keterlambatan berpikir, merespon rangsangan dan kemampuan untuk beradaptasi. Namun mereka lebih baik daripada anak tuna grahita. Mereka membutuhkan waktu belajar lebih lama dibandingkan dengan anak sebayanya sehingga mereka memerlukan layanan pendidikan khusus. Ciri-ciri yang dapat diamati pada anak lamban belajar adalah sebagai berikut: rata-rata prestasi belajar rendah, menyelesaikan tugas-tugas akademik sering terlambat jika dibandingkan dengan teman-teman seusianya, daya tangkap terhadap pelajaran lambat dan pernah tidak naik kelas. Jadi, anak lamban belajar adalah anak dengan kondisi kemampuan intelektual di bawah rata-rata dan memerlukan layanan pendidikan khusus.

Pemerintah pun telah mengatur tentang pendidikan inklusif dalam Peraturan Menteri Pendidikan Nasional Republik Indonesia Nomor 70 Tahun 2009 tentang Pendidikan Inklusif Bagi Peserta Didik yang Memiliki Kelainan dan Memiliki Potensi Kecerdasan dan/atau Bakat Istimewa. (Permendiknas RI, 2009). Pada kenyataannya, anak-anak yang termasuk kelompok lamban belajar banyak ditemukan di sekolah-sekolah umum yang tidak menyelenggarakan pendidikan inklusif, termasuk di sekolah penulis. Peserta didik lamban belajar akan mengalami berbagai hambatan selama proses pembelajaran berlangsung. Oleh karena itu guru matematika harus dapat memberikan penyelesaian terhadap hambatan yang dialami peserta didik tersebut agar tidak ditemukan lagi saat proses pembelajaran selanjutnya. Hambatan-hambatan yang terjadi harus dapat ditangani dengan cepat agar peserta didik lamban belajar dapat mengikuti pembelajaran matematika bersama peserta didik lainnya sehingga dapat mencapai hasil belajar yang optimal.

Pada pembelajaran matematika materi aljabar, peserta didik lamban belajar sering mengalami kesulitan dalam memahami konsep tentang aljabar, mulai dari mengenali bentuk aljabar dan unsurunsurnya, melakukan operasi pada bentuk aljabar, hingga menyelesaikan soal berkaitan dengan bentuk aljabar. Contoh kesalahan yang sering penulis temui misalnya $x+x=x, x+x=x^{2}$, $x . x=x, . x=2 x, x+y=x y$, dan masih banyak lagi kesalahan yang dialami peserta didik lamban belajar terkait materi aljabar.

Menurut Soedjadi (2000), matematika adalah pengetahuan yang bersifat eksak dan mempunyai objek kajian yang bersifat abstrak. Salah satu materi yang memiliki karakteristik abstrak adalah materi aljabar. Untuk memudahkan peserta didik dalam memahami konsep matematika yang abstrak, perlu digunakan benda-benda konkret sebagai media pembelajaran.

Media pembelajaran berupa benda-benda konkret adalah segala alat atau benda nyata yang digunakan untuk membantu tercapainya tujuan pembelajaran. Media konkret adalah segala sesuatu yang nyata dapat digunakan untuk menyalurkan pesan dari pengirim ke penerima sehingga dapat merangsang pikiran, perasaan, perhatian dan minat peserta didik dan menyebabkan proses pembelajaran bisa berjalan lebih efektif untuk mencapai tujuan yang diharapkan (Udin S, 2009). Sejalan dengan itu, Manov (2007) menyatakan bahwa pada dasarnya peserta didik belajar melalui hal yang konkret untuk memahami konsep yang abstrak, artinya peserta didik memerlukan bendabenda konkret sebagai perantara atau visualisasinya. Dengan menggunakan media yang sesuai dengan kondisi atau kebutuhan peserta didik, maka peserta didik akan aktif dan asyik belajar tanpa ada rasa tertekan atau tegang sehingga pembelajaran menjadi lebih efektif dan menyenangkan. 
Dengan demikian jelaslah bahwa salah satu jenis media pembelajaran matematika adalah benda konkret, yaitu media pembelajaran yang berasal dari benda-benda nyata yang banyak dikenal peserta didik dan mudah didapatkan di lingkungan sekitar. Berdasarkan kenyataan di atas, penulis merancang suatu penelitian tindakan kelas pada pembelajaran matematika materi aljabar dengan menggunakan media daun-daun khususnya bagi peserta didik lamban belajar.

Untuk penelitian ini, penulis menggunakan media benda konkret berupa daun-daun. Media daundaun ini sebagai benda konkret untuk mempelajari konsep materi aljabar. Media daun-daun mudah didapat baik di lingkungan sekolah maupun di lingkungan tempat tinggal peserta didik lamban belajar. Semua jenis daun dapat digunakan sebagai media pembelajaran materi aljabar, namun lebih baik dipilih daun yang ukurannya tidak terlalu besar dan juga tidak terlalu kecil. Media daun-daun dapat memberi pengalaman nyata bagi peserta didik didik lamban belajar serta menarik minat belajar mereka untuk aktif dalam proses pembelajaran matematika.

Pembelajaran ini diharapkan efektif dan menarik karena peserta didik lamban belajar dapat berpartisipasi aktif dalam proses pembentukan pengetahuan dengan menggunakan media konkret daun-daun sehingga konsep tentang materi aljabar akan tertanam lebih dalam dan peserta didik lamban belajar dapat meningkatkan hasil belajar matematikanya.

Menurut Nana Sudjana, hasil belajar adalah kemampuan-kemampuan yang dimiliki siswa setelah ia menerima pengalaman belajarnya. (Sudjana, 2014). Dapat dikatakan bahwa hasil belajar peserta didik merupakan hasil akhir proses belajar pada waktu yang ditentukan yang dikontrol oleh proses evaluasi guru.

Berdasarkan latar belakang masalah yang telah dipaparkan, dirumuskan permasalahan sebagai berikut: Bagaimanakah media daun-daun dalam meningkatkan hasil belajar materi aljabar peserta didik lamban belajar (slow learner) di SMPN 18 Tangerang?

Penelitian ini penulis aplikasikan pada pembelajaran materi aljabar kelas VII semester ganjil. Kompetensi dasarnya adalah: 3.5. Menjelaskan bentuk aljabar dan melakukan operasi pada bentuk aljabar (penjumlahan, pengurangan, perkalian, dan pembagian), dan 4.5. Menyelesaikan masalah yang berkaitan dengan bentuk aljabar dan operasi pada bentuk aljabar.(Permendikbud RI, 2016). Penulis merencanakan penelitian tindakan kelas ini menjadi dua siklus dengan siklus 1 terdiri dari 3 pertemuan dan siklus 2 untuk 2 pertemuan.

\section{METODE PENELITIAN}

\subsection{Waktu dan Tempat Penelitian}

Penelitian tindakan kelas ini dilaksanakan pada minggu pertama hingga minggu keempat bulan Oktober 2017 di SMPN 18 Tangerang pada kelas VII.2 tahun pelajaran 2017/2018 untuk materi aljabar di mana semua proses pembelajarannya dilaksanakan dengan menggunakan media daundaun. Berdasarkan hasil belajar matematika yang diperoleh sebelumnya serta berdasarkan hasil pengamatan penulis, dari jumlah seluruh peserta didik kelas VII.2 sebanyak 36 orang, terdapat 16 orang peserta didik yang dikategorikan lamban belajar (slow learner). Obyek penelitiannya adalah hasil belajar matematika peserta didik lamban belajar.

\subsection{Instrumen Penelitian}

Instrumen dalam penelitian tindakan kelas ini adalah tes hasil belajar. Instrumen ini digunakan sebagai alat ukur hasil belajar matematika materi aljabar bagi peserta didik lamban belajar. Bentuk tes yang digunakan adalah tes tertulis berbentuk uraian berjumlah sepuluh soal untuk setiap siklus.

Penulis juga menggunakan lembar refleksi yang diisi oleh peserta didik lamban belajar untuk mengetahui tanggapan mereka terhadap pelaksanaan pembelajaran. Penulis memberi kebebasan kepada semua peserta didik lamban belajar untuk mengungkapkan hal-hal yang mereka alami dan rasakan selama mengikuti pembelajaran.

Untuk memberikan gambaran dan memperjelas bukti pelaksanaan tindakan kelas, penulis mempersiapkan dokumentasi berupa dokumen pembelajaran seperti RPP, data peserta didik, data 
nilai peserta didik dan gambar atau foto yang diambil dengan kamera pada saat proses pembelajaran berlangsung.

\subsection{Prosedur Penelitian}

\section{a. Perencanaan}

Pada tahap perencanaan, yang dilakukan adalah: mengidentifikasi banyaknya peserta didik lamban belajar; menganalisis masalah rendahnya hasil belajar peserta didik lamban belajar; menentukan rencana tindakan termasuk alokasi waktu pelaksanaan penelitian; menyusun rencana pelaksanaan pembelajaran (RPP); menyiapkan instrumen penelitian; menginformasikan kepada semua peserta didik tentang rencana pelaksanaan pembelajaran materi aljabar menggunakan media daun-daun; membagi peserta didik menjadi kelompok-kelompok heterogen yang terdiri dari 4 sampai 5 orang peserta didik per kelompok.

\section{b. Pelaksanaan Tindakan}

Siklus I dilaksanakan dalam tiga pertemuan (6 x 40 menit) termasuk pelaksanaan tes hasil belajar siklus I di akhir pertemuan ketiga. Siklus kedua direncanakan dalam dua pertemuan (4 x 40 menit). Pada tahap ini, kegiatan yang penulis lakukan adalah melaksanakan proses pembelajaran materi aljabar dengan menggunakan media daun-daun, disesuaikan dengan rencana pelaksanaan (RPP) yang telah penulis persiapkan.

\section{c. Pengamatan}

Pada tahap pelaksanaan tindakan, sekaligus dilakukan pengamatan secara seksama dan berfokus pada permasalahan penelitian. Selama berlangsungnya pelaksanaan pembelajaran, penulis mengamati dan mencatat semua hal yang terjadi selama proses pembelajaran. Jika ditemukan hal lain di luar substansi yang terdapat pada instrumen penelitian, akan dijadikan informasi tambahan yang dapat memperjelas data penelitian. Pengamatan ini juga sebagai bahan refleksi di akhir siklus.

\section{d. Refleksi}

Semua data yang diperoleh dari hasil pengamatan dan hasil evaluasi belajar peserta didik, dikumpulkan dan dianalisis. Selanjutnya penulis melakukan refleksi berdasar data tersebut, untuk mencari jawaban apakah kegiatan yang telah dilaksanakan dalam pembelajaran materi aljabar menggunakan media daun-daun dapat meningkatkan hasil belajar matematika peserta didik lamban belajar.

\subsection{Data dan Teknik Pengumpulan Data}

Jenis data utama yang digunakan dalam penelitian ini adalah data kuantitatif yang diperoleh dari nilai tes hasil belajar peserta didik lamban belajar untuk masing-masing siklus.

Teknik pengumpulan datanya adalah tes hasil belajar, yang digunakan untuk mengukur kemampuan peserta didik lamban belajar dalam pencapaian hasil belajar materi aljabar.

\subsection{Indikator Keberhasilan}

Indikator keberhasilan dalam penelitian terkait pembelajaran materi aljabar menggunakan media daun-daun bagi peserta didik lamban belajar ini adalah terdapat $70 \%$ atau lebih peserta didik lamban belajar yang memperoleh hasil belajar sama atau lebih dari nilai kriteria ketuntasan minimal (KKM) yaitu 70.

\subsection{Teknik Analisis Data}

Data hasil belajar peserta didik lamban belajar dianalisis secara deskriptif untuk masing-masing siklus. Peserta didik lamban belajar dikatakan tuntas jika hasil belajarnya mencapai skor $\geq 70$. Persentase ketuntasan klasikal dihitung dengan rumus: $\frac{\text { jumlah peserta didik lamban belajar yang tuntas }}{\text { jumlah peserta didik lamban belajar }} .100 \%$. 


\section{HASIL PENELITIAN DAN PEMBAHASAN}

\subsection{Hasil Penelitian Siklus I}

Pelaksanaan pembelajaran dikondisikan dengan pembelajaran kooperatif bagi semua peserta didik sesuai jadwal pembelajaran matematika yang penulis laksanakan di kelas VII.2. Peserta didik dibagi dalam kelompok-kelompok kecil beranggotakan 4 sampai 5 orang dan semua peserta didik lamban belajar tersebar pada setiap kelompok. Tujuan pengelompokan ini adalah agar peserta didik yang tidak termasuk lamban belajar dan peserta didik yang lamban belajar dapat saling berkolaborasi, belajar dan bekerja bersama-sama, serta peserta didik yang tidak termasuk lamban belajar dapat membantu temannya yang lamban belajar selama proses pembelajaran berlangsung.

Siklus I terdiri dari tiga pertemuan dengan perincian materi dan tujuan pembelajaran sebagai berikutt: (1) Bentuk aljabar dan unsur-unsurnya (memahami pengertian variabel, suku, koefisien, suku sejenis, suku tidak sejenis, koefisien positif, koefisien negatif dan konstanta); (2) Operasi penjumlahan dan pengurangan pada bentuk aljabar (menyelesaikan operasi penjumlahan dan pengurangan suku banyak/polinom yaitu suku-suku sejenis dan suku-suku tidak sejenis); (3) Operasi perkalian dan pembagian pada bentuk aljabar (menyelesaikan operasi perkalian dan pembagian bentuk aljabar).

Kegiatan yang dilakukan pada tahap ini adalah melaksanakan proses pembelajaran materi aljabar menggunakan media daun-daun, sesuai dengan rencana pelaksanaan pembelajaran (RPP) yang telah dibuat.

\section{a. Pertemuan Kesatu}

Pertemuan kesatu dilaksanakan dengan materi bentuk aljabar dan unsur-unsurnya. Sebelum pembelajaran dimulai, semua peserta didik duduk dalam kelompoknya masing-masing dan sudah mempersiapkan bermacam-macam daun yang diambil dari lingkungan sekolah maupun lingkungan rumah serta alat dan bahan lain yang dibutuhkan yaitu karet gelang atau tali rafia, pisau atau gunting, kertas, spidol, selotip/double tape. Setiap kelompok menyiapkan paling sedikit tiga jenis daun, masing-masing jenis terdiri dari 10 sampai dengan 25 helai daun.

Peserta didik diarahkan untuk memahami pengertian variabel, suku, koefisien, suku sejenis, suku tidak sejenis, koefisien positif, koefisien negatif dan konstanta dengan media daun-daun. Pada pembelajaran pertemuan pertama ini, media daun-daun digunakan dengan cara sebagai berikut: satu jenis daun diberi lambang satu variabel, jenis daun yang sama melambangkan variabel yang sama, daun dengan posisi tegak (menghadap ke atas atau tidak terbalik) melambangkan variabel dengan koefisien positif, daun dengan posisi terbalik melambangkan variabel dengan koefisien negatif.

Gambar berikut adalah contoh posisi daun-daun yang melambangkan variabel dengan koefisien positif dan variabel dengan koefisien negatif:

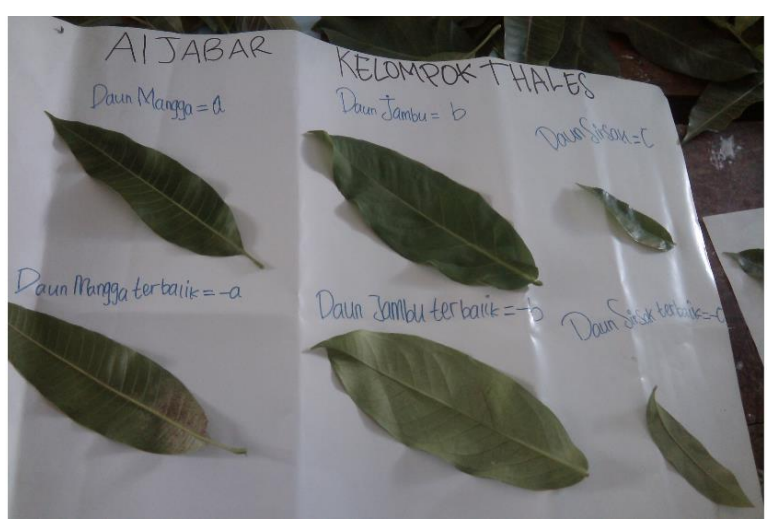

Gambar 1. Daun-daun melambangkan variabel koefisien positif dan negatif

Untuk memahami pengertian koefisien dan konstanta, diawali dengan satu jenis daun yang diberi lambang satu variabel yang ditulis dalam dua cara yaitu dengan tanpa menuliskan angka 1 di depan variabel serta dengan menuliskan angka 1 di depan variabel. Kemudian daun jenis lain (sebanyak 
dua buah) yang melambangkan variabel yang berbeda dengan variabel sebelumnya, ditulis dengan menuliskan variabel dengan angka 2 di depannya yang menunjukkan banyaknya daun tersebut. Dari sini, peserta didik diarahkan untuk menemukan konsep tentang koefisien. Selanjutnya, dari bentuk aljabar $x$ atau $1 x$ dan $2 x$ yang telah digunakan tadi, guru mengambil daun-daunnya dan kemudian bertanya kepada peserta didik bagaimana harus menuliskan bentuk aljabarnya jika tanpa daundaunnya, maka pengertian tentang konstanta ditanamkan kepada peserta didik. Variabel yang mengandung perpangkatan atau variabel berpangkat dilambangkan dengan daun yang diberi tali rafia atau karet gelang, banyaknya tali rafia atau karet gelang sesuai dengan pangkat variabel tersebut.

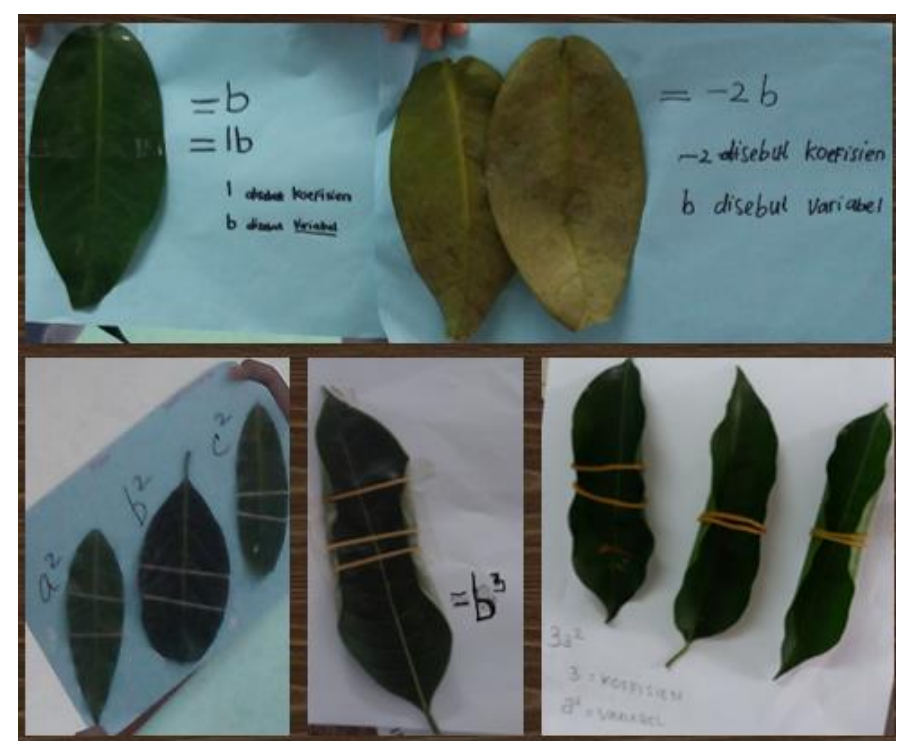

Gambar 2. Daun-daun, karet gelang dan tali rafia untuk mengenalkan bentuk aljabar

\section{b. Pertemuan Kedua}

Pertemuan kedua dengan materi menyelesaikan operasi penjumlahan dan pengurangan pada bentuk aljabar. Menjumlahkan suku-suku sejenis berarti menggabungkan daun-daun yang sejenis. Misalnya untuk menyelesaikan operasi penjumlahan $3 x+4 x$ maka yang pertama dilakukan adalah melambangkan variabel $x$ dengan satu jenis daun. Jika variabel $x$ dilambangkan dengan daun mangga, maka $3 x+4 x$ berarti 3 helai daun mangga digabungkan dengan 4 helai daun mangga, dan hasilnya adalah 7 helai daun mangga yang berarti sama dengan $7 x$.

Mengurangkan suku-suku sejenis berarti menjumlahkan atau menggabungkan dengan daun-daun yang sejenis dengan posisi terbalik. Peserta didik diingatkan tentang sifat operasi pengurangan pada bilangan bulat bahwa mengurangkan dengan suatu bilangan berarti menambahkan dengan lawannya. Misalnya operasi pengurangan $5 x-2 x$ dapat dituliskan $5 x+(-2 x)$, dan cara menyelesaikannya adalah dengan cara menggabungkan 5 helai daun mangga (dengan posisi menghadap ke atas atau tidak terbalik) dengan 2 helai daun mangga dengan posisi terbalik. Selanjutnya 2 helai daun mangga dengan posisi tidak terbalik disatukan dengan 2 helai daun mangga dengan posisi terbalik, menghasilkan bilangan 0 (nol), sehingga sisanya tinggal 3 helai daun mangga dengan posisi tidak terbalik yang berarti $3 x$. Selanjutnya hasil kerja kelompok dipresentasikan di depan kelas serta dipajang pada dinding kelas. 


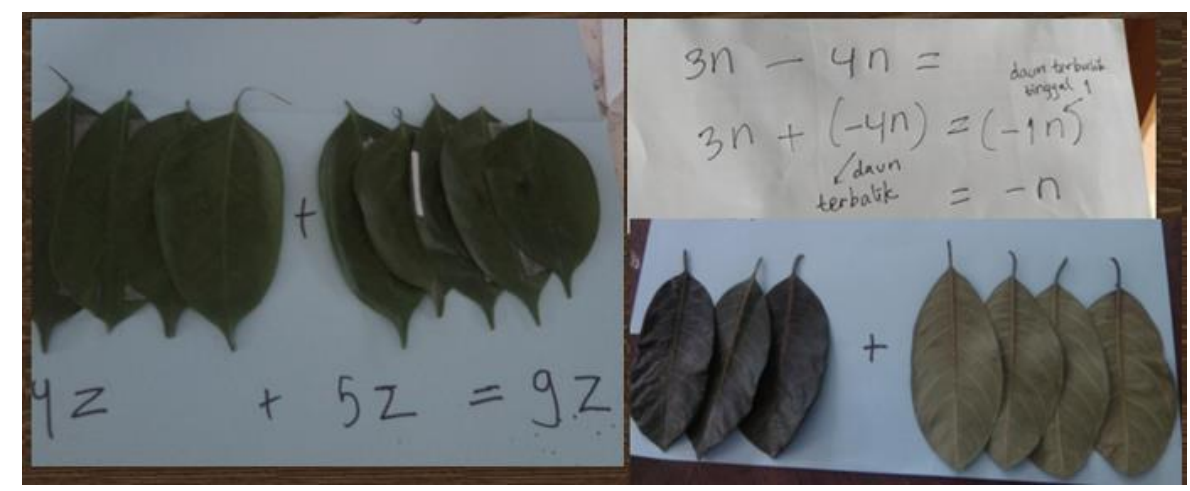

Gambar 3. Operasi penjumlahan dan pengurangan menggunakan media daun-daun

\section{c. Pertemuan Ketiga}

Pada pertemuan ketiga, peserta didik diajak untuk menemukan dan memahami aturan dalam operasi perkalian dan pembagian bentuk aljabar menggunakan daun-daun. Untuk menyelesaikan operasi perkalian, yang harus dilakukan lebih dulu adalah mengalikan koefisien-koefisien variabelnya, sama seperti mengalikan bilangan bulat. Hasil kali koefisien-koefisien ini nanti akan menjadi koefisien dari hasil kali variabel-variabelnya. Selanjutnya perkalian variabel-variabelnya dilakukan dengan cara menggabungkan daun-daun secara berjajar atau berjejer.

Misalnya: variabel $a$ dikalikan variabel $b$, dituliskan $a b$ atau $a . b$ atau $a x b$. Jika variabel $a$ dilambangkan dengan daun jambu dan variabel $b$ dilambangkan dengan daun sawo, maka $a . b$ dilambangkan dengan daun jambu dijejer dengan daun sawo. Karena koefisiennya masing-masing 1 maka $1 \times 1=1$. Sehingga $1 a \cdot 1 b=1 a b$ atau tidak perlu dituliskan koefisiennya, menjadi $a \cdot b=a b$

Contoh lainnya adalah $n . n$ atau $n x n$ dilambangkan dengan 1 daun nangka dijejer dengan 1 daun nangka, selanjutnya dapat diwakili dengan 1 daun nangka saja (karena jenis daunnya sama) dan diberi 2 ikatan karet gelang atau tali rafia, yang melambangkan $n^{2}$

Cara menyelesaikan operasi pembagian bentuk aljabar menggunakan daun-daun hampir sama dengan operasi perkalian, yaitu dengan lebih dulu membagi koefisien-koefisien variabelnya, baru kemudian menjejerkan (atau bisa dengan menyusun ke bawah) variabel-variabelnya yang berarti mengurangi jumlah ikatan atau tali rafianya.

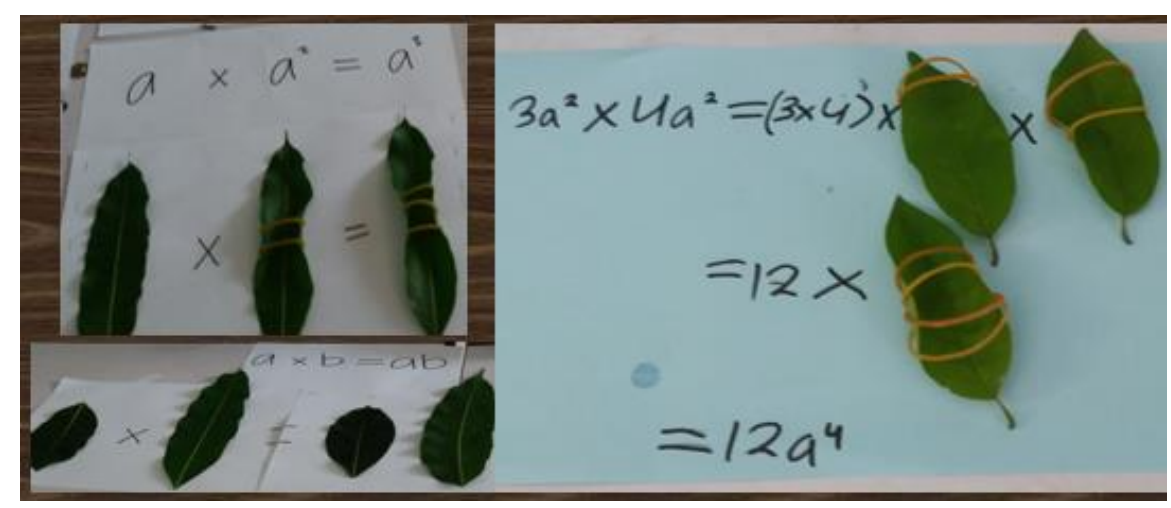

Gambar 4. Operasi perkalian menggunakan media daun-daun

Untuk mengukur hasil belajar peserta didik, pada akhir pertemuan ketiga, peserta didik mengerjakan tes hasil belajar siklus I secara individu. Beberapa peserta didik masih mengingat cara penyelesaian dengan menggunakan media daun-daun, seperti terlihat pada gambar berikut: 


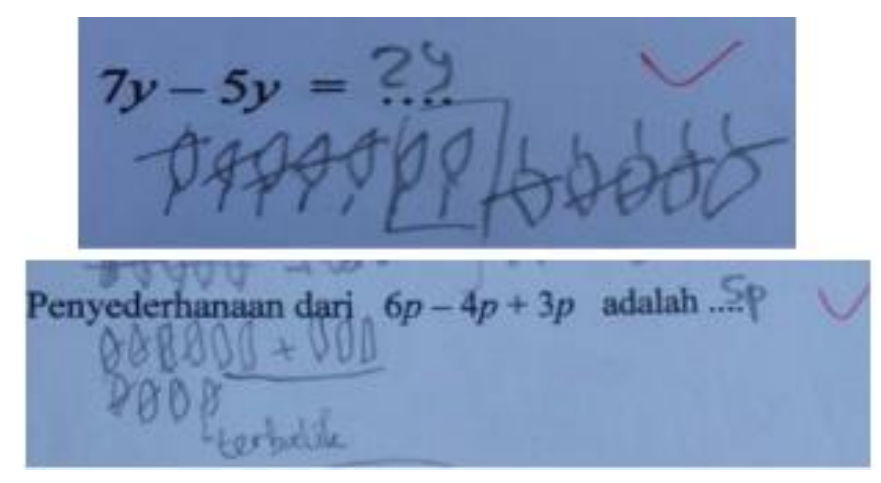

Gambar 5. Peserta didik menyelesaikan operasi aljabar dengan menggambar daun-daun

Refleksi yang dilakukan menunjukkan bahwa pembelajaran yang dilaksanakan guru pada siklus I sudah sesuai dengan rencana pelaksanaan pembelajaran (RPP). Pembelajaran dengan menggunakan media daun-daun pada materi aljabar yang telah dilaksanakan memiliki dampak sebagai berikut: (1) Sebelum pelaksanaan pembelajaran menggunakan media daun-daun, peserta didik lamban belajar merasa kesulitan dan enggan berpartisipasi dalam bekerja kelompok, masih kurang konsentrasi dan tidak mau bertanya. Setelah pelaksanaan tindakan pada siklus I, peserta didik lamban belajar merasa tertarik dan mau diajak bekerja sama dalam mengerjakan tugas kelompok, mereka berusaha lebih konsentrasi dan bisa diajak berdiskusi dengan teman-teman kelompoknya. Guru terus membimbing semua peserta didik. Peserta didik yang tidak lamban belajar diingatkan untuk membantu temannya yang lamban belajar agar bisa lebih memahami materi yang sedang dipelajari; (2) Sebelum pelaksanaan pembelajaran menggunakan media daun-daun, peserta didik tidak terbiasa melakukan presentasi di depan kelas. Setelah pelaksanaan pembelajaran siklus I, cukup banyak peserta didik yang akhirnya mau mencoba presentasi di depan kelas, termasuk beberapa peserta didik lamban belajar. Guru selalu mengingatkan kepada semua peserta didik agar saling menghormati dan menghargai pendapat temannya terutama pada waktu diskusi kelas. Guru juga mendampingi peserta didik lamban belajar yang mencoba mempresentasikan hasil kerja kelompoknya. Meskipun masih merasa grogi dan takut, pada akhirnya mereka merasa senang dan lebih percaya diri setelah berhasil melakukan presentasi di depan kelas; (3) Guru selalu memberikan reward berupa pujian, elusan di pundak atau tepuk tangan bersama untuk peserta didik maupun kelompok yang berpartisipasi aktif dalam bertanya jawab, berdiskusi dan presentasi. Hasil kerja kelompok juga dipajang di dinding kelas. Hal ini membawa dampak positif karena peserta didik merasa bangga dan merasa dihargai hasil kerjanya, khusus untuk peserta didik lamban belajar menjadi lebih percaya diri untuk berpartisipasi secara aktif pada pembelajaran matematika.

Secara umum, pelaksanaan pembelajaran materi aljabar menggunakan media daun-daun relatif lancar karena sejak awal penulis sudah menginformasikan kepada seluruh peserta didik termasuk peserta didik lamban belajar tentang rencana pelaksanaan pembelajarannya. Dari refleksi yang penulis lakukan bersama semua peserta didik pada setiap akhir pertemuan, peserta didik menyatakan senang mengikuti pembelajaran matematika materi aljabar menggunakan daun-daun. Peserta didik lamban belajar menyatakan bahwa mereka menjadi tertarik dan lebih menyukai pembelajaran matematika karena menggunakan media daun-daun. Mereka mengatakan bahwa selain daun-daun mudah didapatkan dari lingkungan sekitar, pembelajarannya menjadi unik karena daun-daun bisa dimanfaatkan untuk belajar matematika. Mereka juga menjadi lebih mudah memahami materi aljabar. Peserta didik merasa dihargai karena guru memberikan pujian, elusan di pundak dan tepuk tangan bersama sebagai penghargaan setelah presentasi hasil kerja kelompok. Peserta didik lamban belajar merasa terbantu dengan bekerja kelompok karena bisa bertanya dan diajari oleh teman-teman sesama anggota kelompok. Gambar berikut adalah contoh refleksi oleh peserta didik: 


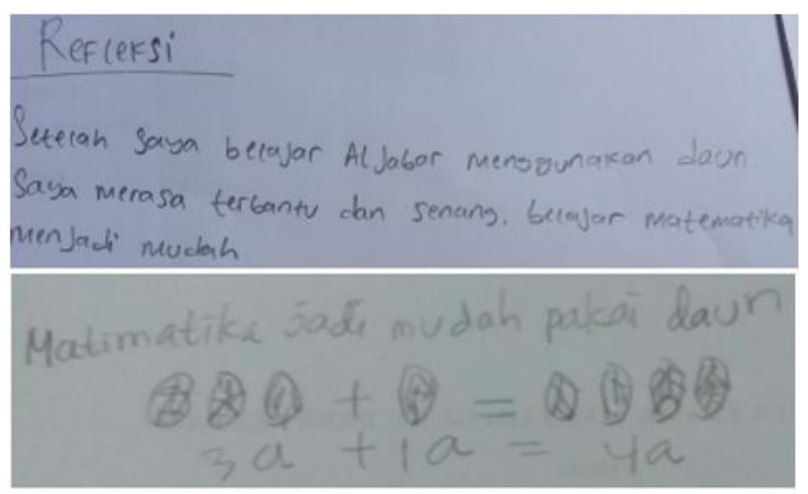

Gambar 6. Refleksi peserta didik

\subsection{Pembahasan Hasil Belajar Siklus I}

Proses pembelajaran siklus I dilaksanakan sesuai dengan rencana pelaksanaan pembelajaran (RPP) yang telah dirancang sebelumnya. Data hasil belajar peserta didik lamban belajar pada siklus I dapat dilihat pada tabel berikut:

Tabel 1. Data Hasil Belajar Peserta Didik Lamban Belajar

\begin{tabular}{|c|c|c|}
\hline No & Nama & $\begin{array}{c}\text { Skor Hasil } \\
\text { Belajar Siklus I }\end{array}$ \\
\hline 1 & Peserta didik 1 & 70 \\
\hline 2 & Peserta didik 2 & 45 \\
\hline 3 & Peserta didik 3 & 50 \\
\hline 4 & Peserta didik 4 & 75 \\
\hline 5 & Peserta didik 5 & 80 \\
\hline 6 & Peserta didik 6 & 40 \\
\hline 7 & Peserta didik 7 & 70 \\
\hline 8 & Peserta didik 8 & 70 \\
\hline 9 & Peserta didik 9 & 75 \\
\hline 10 & Peserta didik 10 & 70 \\
\hline 11 & Peserta didik 11 & 75 \\
\hline 12 & Peserta didik 12 & 70 \\
\hline 13 & Peserta didik 13 & 75 \\
\hline 14 & Peserta didik 14 & 75 \\
\hline 15 & Peserta didik 15 & 35 \\
\hline 16 & Peserta didik 16 & 75 \\
\hline & Jumlah peserta didik tuntas & 12 \\
\hline & Jumlah peserta didik tidak tuntas & 4 \\
\hline & Persentase peserta didik tuntas & $75 \%$ \\
\hline
\end{tabular}


Data pada tabel 1 menunjukkan bahwa dari 16 orang peserta didik lamban belajar, terdapat 12 orang yang memperoleh skor hasil belajar $\geq 70$. Sebelum pelaksanaan pembelajaran menggunakan media daun-daun, peserta didik lamban belajar selalu memperoleh nilai kurang dari nilai kriteria ketuntasan minimal. Setelah pelaksanaan tindakan pada pembelajaran siklus I, diperoleh persentase ketuntasan belajar peserta didik lamban belajar pada siklus I sebesar 75\%. Ini berarti ketuntasan individu masing-masing peserta didik lamban belajar dan persentase ketuntasan klasikal pada siklus I tercapai. Indikator keberhasilan tercapai karena terdapat $70 \%$ atau lebih peserta didik lamban belajar yang memperoleh hasil belajar sama atau lebih dari nilai kriteria ketuntasan minimal (KKM) yaitu 70 . Dapat dikatakan bahwa media daun-daun dapat meningkatkan hasil belajar materi aljabar peserta didik lamban belajar (slow learner) di SMPN 18 Tangerang. Penulis juga mengadakan pembelajaran remedial bagi 4 orang peserta didik lamban belajar yang belum tuntas sehingga mereka bisa mencapai nilai KKM.

Pada penelitian tindakan kelas ini, indikator keberhasilan sudah tercapai di akhir siklus I, karena itu penelitian tidak dilanjutkan dengan siklus kedua. Tercapainya indikator keberhasilan karena adanya beberapa faktor pendukung. Dari literatur rujukan disebutkan bahwa anak lamban belajar membutuhkan waktu belajar yang lebih lama dibandingkan anak pada umumnya, perlu ketelatenan dan kesabaran guru untuk tidak terlalu cepat dalam memberikan penjelasan, perlu penggunaan media pembelajaran yang variatif dan perlu adanya pembelajaran remedial. Anak-anak lamban belajar juga mengalami masalah dalam berkomunikasi, baik dalam menyampaikan ide dan gagasan maupun dalam memahami percakapan orang lain (Thomas Tan, 2017). Pembelajaran kooperatif yang penulis lakukan cukup membantu peserta didik lamban belajar. Guru selalu mengingatkan agar peserta didik yang tidak lamban belajar memberikan rasa empati dan kepedulian yang tinggi dalam membantu teman-temannya yang lamban belajar. Dengan bekerja sama dalam kelompok, peserta didik lamban belajar lebih mudah berkomunikasi dengan teman sebayanya. Bimbingan guru yang terus-menerus selama proses pembelajaran merupakan energi positif bagi peserta didik lamban belajar karena mereka merasa diperhatikan dan dihargai hasil kerjanya. Dengan menggunakan media daun-daun, peserta didik lamban belajar terlibat secara langsung (praktik langsung) dalam memahami materi aljabar (learning by doing). Dengan demikian, peserta didik lamban belajar akhirnya memiliki keinginan untuk berpartisipasi secara aktif dalam proses pembelajaran matematika serta termotivasi untuk dapat memahami materi aljabar

Adapun beberapa kendala yang dihadapi dalam penelitian ini adalah: (1) Pembelajaran dengan metode bekerja kelompok, presentasi dan diskusi kelas dengan jumlah peserta didik lamban belajar yang cukup banyak, tentu memerlukan perhatian ekstra. Meskipun guru terus berusaha memonitor dan mendampingi semua kelompok secara bergantian, pengaturan waktu belum bisa berjalan sebagaimana yang direncanakan sehingga melampaui jam belajar matematika; (2) Papan pajang untuk memajang hasil kerja peserta didik di kelas (gallery work) hanya berupa papan tulis kecil sehingga hanya bisa menampung sebagian kecil dari hasil kerja peserta didik, sisanya dipajang di dinding kelas; (3) Karena menggunakan daun-daun sebagai media pembelajaran, maka nantinya pasti akan layu, untuk itu diperlukan dokumentasi yang nantinya bisa dicetak dan dipajang di kelas; (4) Karet gelang yang digunakan sebagai ikatan pada daun untuk melambangkan variabel berpangkat dipilih karet gelang yang berdiameter kecil agar tidak longgar, tali rafia juga harus dipotong tipis (kecil) agar tampak rapi. Untuk selanjutnya bisa juga dicoba penggunaan kertas label atau double tape sebagai ganti karet gelang atau tali rafia; (5) Untuk lebih memotivasi kerja kelompok, pemberian reward nanti bisa dipertimbangkan berupa tempelan berbentuk daun-daun, bunga atau bentuk lainnya yang dibuat dari kertas, kemudian ditempelkan pada papan nama semua kelompok yang sudah dipersiapkan oleh guru. 


\section{SIMPULAN DAN SARAN}

Berdasarkan hasil penelitian yang telah diuraikan sebelumnya, maka simpulan dan saran yang penulis sampaikan adalah: (1) Media daun-daun dapat meningkatkan hasil belajar materi aljabar peserta didik lamban belajar (slow learner) di SMPN 18 Tangerang; (2) Peserta didik lamban belajar merasa tertarik dan senang mengikuti pembelajaran matematika menggunakan media daun-daun, untuk itu guru harus terus berupaya lebih kreatif dan inovatif dalam menggunakan media pembelajaran, terutama untuk menciptakan pembelajaran yang bermakna bagi peserta didik lamban belajar; (3) Untuk materi aljabar, di samping menggunakan media daun-daun secara langsung, guru bisa mencoba membuat programnya dengan berbasis information technology (IT); (4) Sekolah sebaiknya melengkapi sarana/ prasarana yang diperlukan untuk mendukung pembelajaran di kelas yang lebih baik; (5) Kepala Sekolah hendaknya selalu mendukung guru dalam melakukan inovasi pembelajaran; (6) Sebaiknya dilakukan penelitian lebih lanjut tentang penggunaan media daun-daun atau media pembelajaran lainnya untuk mencapai tujuan pembelajaran matematika yang lebih efektif.

\section{DAFTAR PUSTAKA}

Cahya, Laili S. (2013). Adakah ABK di Kelasku, Bagaimana Guru Mengenali ABK di Sekolah. Yogyakarta: Familia (Grup Relasi Inti Media, anggota IKAPI).

Manov, S. A. (2007). Strategi Pembelajaran Matematika. Jakarta: Universitas Terbuka.

Nana Sudjana. (2014). Penilaian Hasil Proses Belajar Mengajar. Bandung Remaja Rosdakarya.

Permendikbud RI No 24 Tahun 2016. Kompetensi Inti dan Kompetensi Dasar Pelajaran pada Kurikulum 2013 pada Pendidikan Dasar dan Pendidikan Menengah. Jakarta.

Permendiknas RI No 70 Tahun 2009. Pendidikan Inklusif Bagi Peserta Didik yang Memiliki Potensi Kecerdasan dan/ atau Bakat Istimewa. Jakarta.

Presiden Republik Indonesia. (2010). Peraturan Pemerintah Republik Indonesia Nomor 17 Tahun 2010 Tentang Pengelolaan dan Penyelenggaraan Pendidikan. Jakarta.

R. Soedjadi. (2000). Kiat Pendidikan Matematika di Indonesia: Konstatasi Keadaan Masa Kini Menuju Harapan Masa Depan. Jakarta: Direktorat Jenderal Pendidikan Tinggi. Departemen Pendidikan Nasional.

Tan, Thomas. (2017). Teaching is an Art: Maximize Your Teaching. Yogyakarta: Deepublish Publisher.

Udin S. Winataputra dkk. (2009). Materi dan Pembelajaran PKn SD. Jakarta: Universitas Terbuka. 